\title{
PENALIDADE E COLÔNIA: DA LIBERDADE PUNITIVA ÀS ORDENAÇÕES FILIPINAS NUMA ANÁLISE DA PUNIBILIDADE DOS HOMENS LIVRES NA CAPITANIA DE PERNAMBUCO
}

\section{PENALTY AND COLONY: FROM THE PUNITIVE LIBERTY TO THE ORDENAÇÕES FIPINAS, AN ANALYSIS OF THE PUNISHMENT OF THE FREE MEN AT THE CAPITANIA DE PERNAMBUCO}

\author{
${ }^{1}$ Karina Nogueira Vasconcelos \\ ${ }^{2}$ Rodrigo Teles de Oliveira
}

\section{RESUMO}

Trata-se de estudo sobre a penalidade aplicada aos homens livres em Pernambuco colonial, desenvolvido por meio da análise da legislação penal vigente entre 1534-1814 e dos processos judiciais. Após um mapeamento de arquivos públicos nacionais e internacionais e de vasta pesquisa bibliográfica e documental, foram coletados dados, informações e documentos capazes de identificar a transição normativa da liberdade punitiva até a aplicabilidade das Ordenações Filipinas, sem deixar de referenciar a presença de uma justiça eclesiástica e a vigência normativa holandesa em Pernambuco e promover, ainda que incipiente, a explicação dessa cultura jurídico-penal colonial distintiva entre os próprios homens livres.

Palavras-chave: Penalidade, Pernambuco colonial, Legislação penal

\begin{abstract}
It's a study about the penalties applied to free men in Pernambuco during the colonial period, developed through the analysis of the penal legislation between 1534-1814 in Pernambuco and the lawsuits. After a mapping of the national and international public files, and a vast bibliographical and documental research, was collected data, information and documents able to identify the normative transition from the punitive liberty to the applicability of the Ordenações Filipinas, also referring the presence of an ecclesiastic justice and dutch justice in Pernambuco holandês and provide, even incipient, an explanation of this juristic-penal culture distinctive among the free men.
\end{abstract}

Keywords: Punishment, Colonial pernambuco, Criminal legislation

\footnotetext{
${ }^{1}$ Doutora em Teoria e Storia dei diritti umani pela Università degli Studi di Firenze, UNIFI, Itália. Professora da Universidade Católica de Pernambuco - UNICAP, Recife - PE (Brasil). E-mail: karina_vas@ @otmail.com

${ }^{2}$ Mestrando em Direito na Faculdade Damas da Instrução Cristã - FADIC, Recife - PE (Brasil).

E-mail: rodrigo tls92@hotmail.com
} 


\section{INTRODUÇÃO}

Aos 25 de setembro de 1534, o rei de Portugal, D. João III, concede ao fidalgo Duarte Coelho Pereira, por meio da Carta de Doação, um pedaço de terra do Brasil composta de 60 (sessenta) léguas a começar do rio de São Francisco e a findar no rio de Santa Cruz, em razão dos muitos serviços por ele prestados à Coroa Portuguesa, sobretudo, a expulsão dos franceses da Ilha de Itamaracá. Em tal documento, D. João III concede à Duarte Coelho a jurisdição criminal destas terras, podendo absolver, bem como condenar qualquer de seus habitantes.

Essa "carta branca" punitiva dada a Duarte Coelho não durou muito tempo, logo se fez necessária uma política de centralização do poder na Colônia, e uma das estratégias foi a imposição das Ordenações do Reino ao agora Governo-geral. Essa exigência de imposições normativo-punitivas fortalecerá o vínculo entre a Metrópole e a Colônia, reproduzindo nesta, por meio das normas trazidas de Portugal, o pluralismo medieval presente na Europa. A partir daí, começa a se delinear a formação de uma cultura jurídica penal na Capitania de Pernambuco.

A punibilidade dos homens livres na capitania de Pernambuco de 1534 a 1814 foi marcada, portanto, pela aplicação livre da penalidade e sua resistente transição para a aplicabilidade das Ordenações do Reino de Portugal, sendo importante referenciar a justiça eclesiástica e a legislação vigente em Pernambuco holandês. Compreender essa transição implicou analisar como foi realizada a imposição de uma legislação alheia à cultura brasileira, tecendo dedicado olhar sobre a estrutura das legislações portuguesas que vigoraram no Brasil, bem como sobre o tratamento penal dispensado aos membros da sociedade pernambucana de acordo com a classe social, pois logo pode ser percebida a discriminação social insculpida na aplicação das leis. Não se trata de uma referência comparativa entre os homens livres e escravos, mas da existência de uma diferenciação nas penas entre os próprios homens livres.

A opção por uma metodologia exegética das normas e regras vigentes no período colonial para captar o modelo punitivo imposto ao homem livre foi possibilitado por ampla pesquisa bibliográfica e documental, antecedida de um mapeamento de museus e arquivos públicos no Estado de Pernambuco, além de alguns estados brasileiros e países europeus (Portugal, Espanha, Holanda, França e Itália). Foram levantados documentos jurídicos, legislativos, objetos de castigo, objetos de arte, alvarás régios, decretos, leis e processos penais. 
Ao final do mapeamento e da coleta de materiais, tornou-se imprescindível a sistematização das fontes com o escopo de conjugar as reflexões teóricas e historiográficas e as informações pesquisadas nas fontes. Foram analisados, sobretudo: processos judiciais, com o fim de identificar a aplicação do direito aos homens livres da capitania pernambucana de acordo com a sua classe social; a Carta de Doação; as Ordenações Filipinas e documentos normativos penais extravagantes.

\section{A LEGISLAÇÃO PENAL SOB O DOMÍNIO PORTUGUÊS NO BRASIL COLONIAL}

Da colonização do Brasil até a sua independência em 1814, vigeram na Metrópole portuguesa, não concomitantemente, 03 (três) diplomas normativos, as Ordenações do Reino - as Ordenações Afonsinas, Manuelinas e Filipinas. Embora houvesse subordinação à Coroa portuguesa, as legislações lá vigentes não tiveram aplicação imediata na Colônia brasileira, além do mais, algumas dessas Ordenações do Reino sequer tiveram aplicação em solo brasileiro.

Em 1500, quando da vinda dos portugueses ao Brasil, estavam em vigor no país lusitano as Ordenações Afonsinas, que possuíam como principais fontes a doutrina do Corpus Iuris e as Decretais do Papa Gregório IX - as Decretales extra Decretum Gratiani vacantes, de 1234. Ou seja, tinham um substancial amparo no Direito romano, compilado por Justiniano e no Direito Canônico.

Embora já seja possível a observação da existência de um tratamento diferenciado entre os membros do corpo social nas Ordenações Afonsinas, esse texto normativo não teve qualquer aplicação no Brasil, visto que, durante a sua vigência, inexistiu qualquer núcleo colonizador português nas terras brasílicas, resumindo-se apenas à existência de feitorias. Nesse mesmo sentido aduz PIERANGELI (2004, p. 61):

\footnotetext{
As Ordenações Afonsinas nenhuma aplicação tiveram no Brasil, pois, quando em 1521 foram revogadas pelas Ordenações Manuelinas, nenhum núcleo colonizador havia se instalado no nosso país. Só em 1532, Martim Afonso de Souza iniciou a colonização, fundando a cidade de São Vicente. Vigiam, portanto, as Ordenações Manuelinas.
}

No inicio da colonização de fato das terras brasileiras a partir de 1532, com Martim Afonso de Souza, e, em Pernambuco, mais especificamente, em 1534, com Duarte Coelho, vigoravam em Portugal as Ordenações Manuelinas (1521), compostas, basicamente, da 
compilação das Ordenações Afonsinas e das várias leis extravagantes que foram surgindo após a promulgação desta. A principal diferença das Ordenações Manuelinas em comparação com as Ordenações Afonsinas não foi o seu conteúdo, mas a forma como as normas eram dispostas, deixando de ser uma Ordenação com um texto discursivo (narrativo), passando a ter um texto mais direto com comandos - imperativos; além de abandonar o critério históricocronológico para adotar o sistemático-sintético na sua organização.

Entretanto, muito embora as Ordenações Manuelinas já estivessem em vigor quando do inicio dos primeiros núcleos colonizadores no Brasil, elas não tiveram muita aplicação nestas terras, sobretudo porque quando da colonização das terras brasileiras, a Coroa portuguesa, por meio das Cartas de Doação, delegou sua jurisdição criminal a alguns fidalgos, os Donatários, a quem doou umas porções de terras, as Capitanias.

As Ordenações Filipinas, contudo, dentre as 03 (três) Ordenações que vigeram durante o período colonial, foi a que, inegavelmente, maior aplicação teve no Brasil, principalmente por ser a legislação em vigor após o enfraquecimento dos poderes jurisdicionais dos donatários, ocorrido com o processo de centralização do poder jurisdicional pela Coroa Portuguesa e com o estabelecimento dos Governos-gerais.

\subsection{A Carta de doação da Capitania de Pernambuco}

A colonização de fato na Capitania de Pernambuco teve início em 1534, quando esta foi doada à Duarte Coelho Pereira por meio da Carta de Doação do Rei D. João III, datada de 25 de setembro de 1534, nomeando aquele como Donatário da faixa de terra brasileira a começar do Rio de S. Francisco e a findar no rio de Santa Cruz. Saliente-se que, embora neste período estivesse em vigor na metrópole portuguesa as Ordenações Manuelinas, estas não tiveram aplicação em solo brasileiro enquanto o sistema de organização do Brasil foi o de Capitanias Hereditárias.

O principal motivo para a inaplicabilidade das Ordenações Manuelinas durante este período pode ser explicado pelo fato de que na Carta de Doação, em que o rei de Portugal doa a Duarte Coelho Pereira a Capitania de Pernambuco, o monarca também concedeu ao novel donatário a jurisdição criminal da alusiva faixa de terra, conforme se pode inferir do fragmento da Carta de Doação de Pernambuco a Duarte Coelho a seguir: 


\begin{abstract}
$1^{\circ}$ Outrosim lhe faço doação e mercê de juro e herdade para sempre ele e seus descendentes sucessores no modo sobredito da jurisdição civil e crime da dita terra, da qual ele dito Duarte Coelho e seus herdeiros, e sucessores uzarão na fórma maneira seguinte.

$2^{\circ}[\ldots]$ e nos casos crimes hei por bem que o dito capitão e governador e seu ouvidor tenhão jurisdição e alçada de morte natural inclusive em escravos, e Gentios; e assim mesmo em piães christãos homens livres, e em todos os casos assim para absolver, como para condemnar sem haver appellação nem agravo, e nas pessoas de maior qualidade terão alçada de dez annos de degredo e até cem cruzados de penna, nem appellação nem aggravo, e porém nos quatro casos seguintes a saber: heresia, quando heretico lhe fôr entregue pelo ecclesiastico e traição e sodomia, e moeda falsa, terão alçada em toda a pessoa de qualquerqualidade que seja para condemnar os culpados á morte, e dar suas sentenças á execução sem appellação, nem aggravo, e porque nos ditos quatro casos para absolver de morte, posto que outra pena lhe queirão dar menos de morte, darão apelação e aggravo por parte da Justiça.[...]

$18^{\circ}[. .$.$] o dito Duarte Coelho, e todos os seus sucessores a que esta Capitania e$ governança vier usem inteiramente de toda a jurisidicção, poder e alçada nesta doação conteúda [...] (grifo nosso).
\end{abstract}

Verifica-se que, não obstante o monarca português tenha cedido sua jurisdição da terra de Pernambuco em favor de Duarte Coelho, ele ainda comina punições à prática de alguns crimes descritos na própria Carta de Doação, ou seja, observa-se que embora não vigesse de fato qualquer corpo normativo em terras pernambucanas, o rei de Portugal salientava algumas condutas que deveriam ser repreendidas pelo donatário. Destaque-se que na própria Carta de Doação é possível verificar que também há uma diferenciação na pena em relação à qualidade do agente.

Ponto importante é compreender que mesmo com a Carta de Doação estabelecendo alguns delitos que deveriam ser punidos, estas condutas tipificadas pelo rei na Carta de Doação não mitigava de forma alguma o grande poderio de Duarte Coelho, posto que este é quem teria o poder jurisdicional, o poder de condenar, bem como absolver qualquer habitante da Capitania de Pernambuco, ou seja, o direito aplicado era aquele determinado pelo arbítrio do donatário. Assim, os donatários nada mais eram do que um fidalgo na pele de um déspota.

Quem bem sintetiza a inaplicabilidade das Ordenações Manuelinas em solo brasileiro no período das capitanias hereditárias é Augusto F. G. Thompson (1976, p. 89) ao afirmar:

Pouca importância tiveram, no Brasil, as Ordenações Manuelinas, embora, formalmente, estivessem vigorando na época das capitanias hereditárias. Abundavam as determinações reais especialmente decretadas para a nova colônia, as quais, aliadas às cartas de doação, com força semelhante à dos forais, abacinavam as regras do código unitário. O arbítrio dos donatários, na prática, é que estatuía o Direito empregado e, como cada um tinha critério próprio, era extremamente caótico o regime jurídico da América. 
Fica claro, portanto, que com a doação da jurisdição criminal para os donatários de cada capitania pela Coroa portuguesa, houve a descentralização do ius puniendi, ficando, estes donatários, como responsáveis/legitimados por conhecer todas as causas criminais no âmbito de sua capitania. Além disso, observa HESPANHA (2012) que o fator financeiro foi bastante relevante para a autonomia da Colônia, isto porque, o incentivo dado à autossuficiência, liberaria a Metrópole de aportes financeiros e, assim, a colonização se tornaria ainda mais rentável.

\subsection{Ordenações do Reino}

Com o insucesso do sistema de Capitanias Hereditárias, visto que das capitanias distribuídas pelo rei apenas a de Pernambuco e a de São Vicente prosperaram, a Coroa portuguesa resolveu, através do Regimento de 17 de dezembro de 1548, centralizar a administração do Brasil. Adotou, para isso, o sistema de Governo-geral e designou o fidalgo Tomé de Sousa para o papel de Governador-geral, o que atingiu diretamente os poderes dos donatários das capitanias no Brasil.

\footnotetext{
Com o fracasso da grande maioria das capitanias, tratou a metrópole de dar à Colônia outra orientação designada como sistema de governadores-gerais. Surgiu, assim, a utilização de um certo número de prescrições decretadas em Portugal, reunindo desde cartas de Doações e Forais das capitanias até CartasRégias, Alvarás, Regimentos dos governadores gerais, leis e, finalmente, as Ordenações Reais. De fato, o Direito vigente no Brasil-Colônia foi transferência da legislação portuguesa contida nas compilações de leis e costumes conhecidos como Ordenações Reais [...] (WOLKMER, 1998, p. 47).
}

Todavia, o início do governo de Tomé de Sousa não obteve qualquer influência nos comandos da Capitania de Pernambuco, isto é, Duarte Coelho, com esteio em sua Carta de Doação, sobretudo em seu título 18, em que proibia a existência de outra jurisdição na capitania que não fosse a do próprio donatário, não permitiu a penetração de qualquer jurisdição estranha a ele em Pernambuco. Tanto que, em sua carta ao rei de Portugal, datada de 24 de novembro de 1550, Duarte Coelho conclama: “(...) e que não se entenda comigo o que tinha mandado a Tomé de Sousa, nem ele venha cá, nem interfira na minha jurisdição" (MELO e ALBUQUERQUE, 2001, p. 85).

A limitação de fato do poder jurisdicional do donatário da Capitania de Pernambuco só ocorrera posteriormente, por meio do Alvará Régio de 05 de março de 1557, quando Duarte Coelho Pereira já não mais era donatário. Com o supramencionado alvará, surge o poder de apelação para outra alçada em alguns delitos, bem como fica decidido que os 
ouvidores das capitanias não mais seriam escolhidos pelos donatários, mas pela Coroa portuguesa. A partir de então, infiltra-se a jurisdição portuguesa em terras pernambucanas, começando a viger as Ordenações do Reino.

\subsubsection{Vigência e aplicação das Ordenações Filipinas no Brasil}

Quando da mitigação dos poderes dos donatários brasileiros ainda estava em vigor as Ordenações Manuelinas. Contudo, é incontestável que o corpo normativo que maior aplicação teve no Brasil, tendo aplicação integral e efetiva, foram as Ordenações Filipinas - OF, promulgadas em 1603 e vigendo por pouco mais de 02 século, até o advento do Código Criminal do Império de 1830, constituindo-se de uma compilação das Ordenações Manuelinas com as diversas leis extravagantes existentes, em Portugal, na época.

Uma das características da Ordenação Filipina era que comumente cominava penas muito cruéis para condutas que, no fundo, podem ser consideradas insignificantes, posto inexistir, de fato, de qualquer lesão ao Estado. Confundia, não raramente o delito com o pecado, até mesmo pelo fato da cultura religiosa da época e do fato das Ordenações terem bebido do Direito Canônico, uma das principais fontes do Direito português à época.

Cabe enfatizar, ainda, que um dos principais objetivos da aplicação do direito penal português no Brasil Colônia era estabelecer, nestas bandas, um ordenamento jurídico criminal impiedoso, com o intuito de se proteger contra ameaças à sua dominação.

Demais disso, embora as OF cominassem penas muito drásticas para a maioria dos delitos, observa-se que essas penas não foram muito utilizadas no Brasil, entre os motivos que levaram à diminuição dessas punições estava a política do perdão, que era muito utilizada pela Coroa real. Assim, como demonstra Luís Francisco Carvalho Filho (2004, p. 183): “(...) por esta dialética do terror e da clemência, o rei constituía-se, ao mesmo tempo, em senhor da Justiça e mediador da Graça”.

Acrescente-se que, muito embora o principal objetivo do estabelecimento dos Governos-gerais era a centralização do poder político-jurisdicional, o primeiro GovernadorGeral do Brasil colonial, Tomé de Sousa utilizou o ius puniendi conforme a sua conveniência. Muito provavelmente isto foi fator preponderante para a pouca utilização das Ordenações Manuelinas em terras brasílicas logo após a instituição do Governo-geral. 


\subsubsection{Estrutura e característica das Ordenações Filipinas}

As Ordenações Filipinas - OF tiveram como principais fontes as Ordenações Manuelinas e as legislações extravagantes. Neste diapasão, pode-se atestar que todas as Ordenações do Reino que vigeram em Portugal, quais sejam, as Ordenações Afonsinas, Manuelinas e Filipinas, beberam do Direito Romano e do Direito Canônico.

Em relação às Ordenações Filipinas, é importante destacar que, embora quando foram promulgadas, em 1603, a Coroa portuguesa estivesse sobre influência da União Ibérica (1580-1640), o código lusitano não teve qualquer tipo de influência do direito espanhol.

Característica importante das Ordenações Filipinas, principalmente em seu Livro V, que dispõe sobre o direito penal e que vigeu em Pernambuco, é que as condutas ali tipificadas como delitos muitas vezes eram posturas que de fato não atingia qualquer bem jurídicoestatal, ou seja, muitas vezes as Ordenações acabavam por incriminar condutas tidas apenas como imorais, logo, deveriam ser consideradas irrelevantes para o Estado. Isto se deu principalmente porque, não raramente, as OF confundiam o ilícito com o pecado. Assim, as OF acabavam por considerar como delitos condutas que atentassem contra a religião oficial do Estado, qual seja, a Católica. Situação esta que pode ser verificada, por exemplo, do Livro V, Título II, das OF, que assim dispõe:

TÍTULO II - DOS QUE ARRENEGAM OU BLASFEMAM DE DEUS OU DOS SANTOS Qualquer que arrenegar, descrer ou pesar de Deus ou de sua Santa Fé, ou disse outras blasfêmias, pela primeira vez, sendo fidalgo, pague vinte cruzados e seja degredado um ano para África.

E sendo cavaleiro ou escudeiro, pague quatro mil réis e seja degredado um ano para África.

E se for peão, dêem-lhe trinta açoites ao pé do pelourinho com baraço e pregão, e pague dois mil réis [...].

Assim, pode-se perceber, portanto, que o Livro V, das Ordenações Filipinas acaba por considerar como delitos, ações que, no fundo, não eram mais do que pecados. Demais disso, resta demonstrado que, além de confundir o crime com o profano, as Ordenações Filipinas, em seu próprio texto normativo, já dispensa um tratamento diferenciado, em relação às penas, a variar de acordo com a qualidade - com a classe social - do agente delituoso.

A discriminação da pena em relação à classe social do agente não era uma valoração apenas realizada posteriormente por meio de uma atividade judicial, mas, no próprio texto normativo, já havia esta distinção de tratamento em relação à punibilidade. 
O Livro V das OF possui um total de 143 títulos, sendo que, referente ao Direito Penal material, o Livro V vai até o título 115, a partir daí começam os dispositivos atinentes ao Direito Penal instrumental, mesmo que ainda possam ser encontrados, nesta segunda parte, alguns dispositivos de Direito Penal substantivo. Embora os tipos penais não fossem distribuídos de maneira sistemática, encontra-se, já a partir daí, um indício de sistematicidade, principalmente porque, embora os dispositivos estivessem agrupados de maneira casuística, já não mais estavam dispostos de forma cronológica, como ocorria nas Ordenações Afonsinas. Assim esclarece Frederico Marques (1997, p. 116):

\begin{abstract}
De par com isto, os preceitos se aglutinavam em uma estrutura primária e rudimentar de indisfarçável empirismo. Falta ao livro V uma parte geral; e na parte especial, os delitos se enumeram casuisticamente, sem técnica apropriada, numa linguagem (muitas vezes pitoresca) em que falta o emprego de conceitos adequados do ponto de vista jurídico. As figuras delituosas se amontoam sem nexo, na ausência de espírito de sistema para catalogá-las, racionalmente, formando muitas vezesverdadeiros pastiches, tal a confusa e difusa redação dos textos em que se condensam as condutas delituosas, e respectivas sanções.
\end{abstract}

Característica marcante das Ordenações Filipinas era a sua intimidação pelo terror, assim, suas penas eram muito drásticas e não proporcionais. Nesse ponto afirma PIERANGELI (2004, p.58) que: "Na previsão de conter os maus pelo terror, a lei não media a pena pela gravidade da culpa; na graduação do castigo obedecia, só, ao critério da utilidade".

Entre as várias penas infamantes continentes no Livro V, a pena mais cominada era a pena de morte, que poderia ser aplicada de 04 (quatro) formas distintas, variando de acordo com o delito cometido. De acordo com a gravidade, de forma decrescente, pode-se afirmar que as OF prescreviam a: (i) Morte cruel, consistente na forma de retirar a vida do agente de forma paulatina, sempre acompanhada de tormento; (ii) Morte atroz, em que, além da pena capital, a vida era retirada seguida de algumas outras circunstâncias agravantes, tais como, a queima do cadáver do sentenciado/condenado, confisco de seus bens, o seu esquartejamento, e até mesmo a proscrição da memória; (iii) Morte simples, configurada pela perda da vida sem qualquer outro requinte de crueldade introduzida em sua execução. Poderia ser executada por degolação ou por enforcamento, a escolha de qual destas duas formas o sentenciado morreria, era feita com base na classe social do agente, haja vista que a pena de morte simples por enforcamento era tida como muito infamante, sendo, portanto, destinada à classe social mais humilde, e; (iv) Morte civil, em que o sentenciado perderia sua vida civil e os direitos da cidadania. 
Embora esses sejam os 04 (quatro) tipos de penas de morte aplicadas, as OF não possuíam um texto claro, trazendo designações confusas para a aplicação de algumas destas formas de pena capital, por exemplo, para designar a morte atroz, às vezes, utilizava-se da expressão "morra morte natural para sempre", que seria a morte simples acrescida do termo "para sempre".

A pena de morte era o castigo mais amplamente cominado no Livro $\mathrm{V}$, sendo considerada a pena por excelência. Entretanto, esta não era a única pena cominada nas OF, pois também eram impostas as penas de multa, degredo (exílio), açoites, cortes de membros (amputação) e de trabalhos forçados (galés), entre outras penas encontradas tanto nas Ordenações, quanto nas legislações extravagantes, variando, a punibilidade, conforme a classe social do indivíduo infrator dessas normas. Como bem aduz PIERANGELI (2004, p. 58): “Além de bárbaras e atrozes, as penas eram desiguais: influía na sanção a qualidade ou condição da pessoa, pois se puniam diversamente os nobres e os plebeus".

Apesar de inexistir no Livro V das Ordenações Filipinas uma "parte geral”, como os existentes nos códigos hodiernos, eles já admitiam a coautoria, aplicando a mesma pena a quem ajudasse o delituoso, a legítima defesa como forma de absolvição, bem como a punição no caso de excesso da legítima defesa, a tentativa e até mesmo crimes culposos, como se observa, neste caso, no Título XXXV, do Livro V, das OF - Dos que matam ou ferem, ou tiram com arcabuz ou besta. Também o erro de tipo como forma de exclusão da pena, a exemplo disto, tem-se o Título XIV, do Livro V, das OF - Do infiel que dorme com alguma cristã e do cristão que dorme com infiel. Acrescente-se a isso, a descriminalização de alguns delitos motivados por emoção, como, por exemplo, o Título XXXVIII, do Livro V, das Ordenações Filipinas - Do que matou sua mulher por a achar em adultério.

Para alguns delitos, a exemplo do disposto no Título CXVIII, $\S 1^{\circ}$, do Livro V, das OF - Dos que querelam maliciosamente ou não provam suas querelas e denunciações, era aplicada a pena arbitrária, quando a fixação da pena ficava a mercê da vontade do juiz, ele quem escolhia qual pena que o sentenciado deveria cumprir. Desta forma, o juiz também se transformava em um pouco de legislador. Constata-se, assim, que não vigorava, nas Ordenações, o princípio da legalidade, haja vista que a pena nem sempre era prévia (Nullum crimen, nulla poena sine lege). Também não vigia na época o princípio da pessoalidade da pena, posto que, no caso dos crimes de lesa-majestade (Título VI, do Livro V, das OF) e de sodomia (Título XIII, do Livro V, das OF), a infâmia era transmitida aos descendentes. 
As penas cominadas nas Ordenações do Reino não visavam a ressocialização do agente infrator, corrobora com esse entendimento o fato da pena de morte ser a mais largamente cominada nas pelas OF. Assim, nas sanções penais prevalecia a "prevenção geral negativa", em que a sociedade se sentia desestimulada a delinquir ao observar as penas aplicadas, em razão da "prevenção especial da pena", que recai sobre o condenado para evitar que volte a delinquir, haja vista que, devido às drásticas sanções aplicadas, o criminoso dificilmente teria a possibilidade de se redimir e retornar à sociedade, ou seja, a pena não exercia um papel ressocializador. Como já demonstrado, o principal objetivo das Ordenações era intimidar o homem por meio do terror.

\subsubsection{Os homens livres no Brasil colonial, em especial na Capitania de Pernambuco}

Dos textos normativos que vigeram em terras brasílicas, pode-se notar a existência de um tratamento diferenciado em relação à qualidade da pessoa que delinquiu e, muitas vezes, em relação à qualidade da vítima. Saliente-se que essa diferenciação dada às pessoas não eram existentes apenas nas leis extravagantes direcionadas ao Brasil, ou nas Cartas de Doação,como a que se infere da Carta de Doação da Capitania de Pernambuco em seu artigo $2^{\circ}$, mas também havia essa distinção nas próprias $\mathrm{OF}$, a exemplo disto, tem-se o Título XXXV, do Livro V, das Ordenações Filipinas - Dos que matam ou ferem, ou tiram com arcabuz ou besta.

De forma geral, tanto na Carta de Doação de Pernambuco quanto nas Ordenações Filipinas, as pessoas de mor qualidade estavam imunes da aplicação de penas vis, tais como, açoites, galés, pregão (anunciação pública da execução da pena), por serem muito infamantes.

Embora houvesse essa distinção, a própria OF, em seu Título CXXXVIII, § $2^{\circ}$, do Livro V, das Ordenações Filipinas - Das pessoas, que são escusas de haver pena vil, excetuava alguns crimes em que não haveria diferenciação entre a classe social dos agentes, seria nos casos dos crimes de grande lesividade para a Coroa portuguesa, tais como, os delitos de lesa-majestade, sodomia, falso testemunho, indução de testemunhas falsas, moeda falsa, bem como qualquer outro crime de falsificação, furto, feitiçaria e alcovitaria.

A Carta de Doação de Pernambuco datada de 25 de setembro de 1534, quando ainda não existiam as Ordenações Filipinas e que passa a jurisdição criminal da Capitania de Pernambuco às mãos de Duarte Coelho Pereira também dispõe, em seu artigo $2^{\circ}$, que o 
donatário, nos casos dos delitos de heresia, traição, sodomia e moeda falsa deveria punir o acusado sem realizar qualquer tipo de distinção em relação à pessoa deste.

Em relação à organização social, esta se definia, de um lado, pela existência de uma elite constituída por grandes proprietários rurais; e de outra banda, por pequenos proprietários, índios, mestiços e negros. Nesta senda, por meio das legislações que vigeram na Capitania de Pernambuco, como, por exemplo, a própria a Carta de Doação e o Regimento de 22 de setembro de 1668, dado ao Ouvidor-geral designado pela Coroa portuguesa à Comarca de Pernambuco, pode-se constatar a existência do seguinte estrato social: (i) nobres; (ii) peões; (iii) gentios e; (iv) escravos.

Constata-se que os nobres eram os proprietários de grandes pedaços de terras, fidalgos, ou seja, a classe da nobreza era formada, essencialmente, pelo donatário, sesmeiros e senhores de engenho. De outra banda, os peões eram formados por pessoas pobres que vinham para o Brasil ou em busca de fortuna ou para cumprir sua pena de degredo. Inferese, portanto, que alguns peões eram pessoas criminosas que tiveram como sanção o exílio para o Brasil, fato este que incomodou bastante o donatário da Capitania de Pernambuco:

\footnotetext{
Duarte Coelho, donatário da capitania de Pernambuco, escreveu pelo menos quatro cartas ao rei reclamando da vinda dos degredados, 'que nenhum fruto nem bem fazem na terra', revelando essa contradição. Diria ele em 1546: '[...] o que Deus nem a natureza remediou, como eu posso remediar, Senhor, senão com cada dia os mandar enforcar [...]' (FILHO, 2004)
}

Em relação aos gentios, considerados homens livres, após a tentativa frustrada de escravização, também eram submetidos ao código lusitano vigente à época, Contudo, dentro das aldeias dos gentios, o que predominava era a legislação criminal criada pelos missionários, especialmente os jesuítas. Constata-se, portanto, a existência de um pluralismo jurídico, com a coexistência de mais de uma ordem normativa no Brasil Colônia.

Em relação aos escravos, eles eram tidos como objetos e, como tal, eram privados de liberdade, não sendo, portanto, considerados como homens livres, existindo, portanto, poucos documentos normativos voltados a eles.

\section{A LEGISLAÇÃO PENAL EM PERNAMBUCO HOLANDÊS}

Com a invasão holandesa na Capitania de Pernambuco, iniciada em 13 de junho de 1630, a legislação da Coroa portuguesa, as Ordenações Filipinas, entra em hiato, deixando

Revista Brasileira de História do Direito | e-ISSN: 2525-9636 | Brasília | v. 2 | n. 1 | p. 261 - 283 | Jan/Jun. 2016. 
de vigorar nas terras pernambucanas por 24 (vinte e quatro) anos, até a retomada da supramencionada capitania pelo Governo de Portugal.

Possuem-se poucas informações acerca do regime jurídico-criminal durante o período em que a Capitania de Pernambuco, a partir de então denominada de "Nova Holanda", ficou sobre o domínio dos holandeses (1630-1654). O que se sabe sobre o direito penal utilizado nesta época é que houve um repúdio às leis portuguesas e, em solo pernambucano, passou a vigorar as leis penais vigentes na Holanda, Zelândia e Frísia, além de algumas outras leis que foram editadas na metrópole e no novel domínio holandês com o intuito de atender às necessidades sociais do novo domínio holandês.

Até a chegada do Conde Maurício de Nassau, em 1637, existiam, na Nova Holanda, muitas leis penais vigorantes, leis oriundas do próprio povo batavo, razão pela qual, para o Conde era necessária revogação das leis penais incriminadoras que cominassem penas leves, deixando em vigor, portanto, apenas aquelas leis penais que punissem os delitos mais graves. Por conseguinte, esta foi a época, durante o período colonial, em que a Capitania de Pernambuco - ou Nova Holanda - conheceu o direito penal como ultima ratio essendi.

Embora durante o domínio holandês de Maurício de Nassau grande parte da legislação criminal tivesse sido revogada, algumas penas atrozes continuaram legitimadas por força normativa - até porque o Conde de Nassau apenas revogou as espécies típicas que cominassem penas leves. Enfatize-se que eram punidos com maior rigidez os portugueses e os nativos que se voltavam contra o domínio holandês e aqueles que atentassem contra os interesses financeiros da WIC - Companhia das Índias Ocidentais, podendo ser aplicadas as penas de prisão, confisco de bens e, provavelmente, até mesmo a pena de expulsão e a de morte.

Outras condutas severamente punidas eram o incesto, a extorsão, os jogos de azar e o adultério. Embora o governo da Nova Holanda reprimisse severamente os duelos, assemelhando-os ao homicídio; em alguns momentos os duelos eram permitidos, quando ocorressem condutas imperadas pela "ira cega" ou pela "justa dor". Assim, delineia-se a excludente de culpabilidade como forma de isenção de pena.

Entretanto, é de suma importância frisar que, em razão de existir informações esparsas acerca do regime jurídico-criminal durante o período da Nova Holanda, não é possível se comprovar a existência de qualquer tipo de distinção na aplicação das penas aos agentes delituosos em razão de sua classe social; apesar de ser possível deduzir pela existência dessa diferenciação em algumas espécies de crimes, visto a existência de uma 
penalidade mais rígida aos portugueses e nativos que se voltavam contra o domínio holandês. Contudo, é inegável que, nos casos de duelos e de homicídios, o Conde de Nassau punia o agente sem ter em conta a condição, a qualidade, do criminoso.

A pena por excelência, assim como no domínio português, era a pena capital. Esta espécie de pena, na Nova Holanda, poderia ser executada de diversas maneiras, como, por exemplo, por meio da forca, espada, fogueira, entrega aos índios, esquartejamento do sentenciado ainda vivo. Não raramente, essas penas capitais eram realizadas com requinte de perversidades, amputando, por exemplo, as mãos do condenado antes do enforcamento.

Os meios de execução preferidos eram a forca, o degolamento e o arcabuzeamento. Nada obstante, embora o direito penal vigente na Nova Holanda também fosse muito cruel, o Conde Maurício de Nassau, assim como ocorreu na época da dominação portuguesa, tentando atenuar o direito penal vigorante, algumas vezes comutava as penas e até mesmo concedia perdões. Desta forma afirma Ruy Rebello Pinho (1953, p. 402), ao comentar da atividade do governador da Nova Holanda: "Era, ao mesmo tempo, chefe religioso, civil e militar. Tinha o direito de perdoar os criminosos ou de comutar-lhes as penas, e desta faculdade Nassau usou com freqüência, 'que era benigno de natureza"”.

Após a expulsão dos holandeses, em janeiro de 1654, a legislação penal utilizada na Capitania de Pernambuco, durante o período holandês foi totalmente descartada, não tendo qualquer tipo de influência futura, voltando a vigorar, desta forma, com proeminência, as Ordenações Filipinas, até a promulgação do Código Penal do Império, em 1830. Assim finaliza Aníbal Bruno (1978, p. 177), ao comentar sobre o período de dominação da Holanda no Brasil colonial, principalmente em Pernambuco:

Essas leis holandesas, de curta vigência e logo repelidas e olvidadas, por força do sentimento nacionalista nascente, que orientou a brava reação da gente brasileira, sobretudo em Pernambuco, contra aquele domínio, não deixaram traços de nenhuma particularidade na legislação definitiva do país. Foram um acidente histórico prontamente esquecido. A lei que voltou a reger foram as Ordenações de Portugal.

\section{MAPEAMENTO E ANÁLISE DOS PROCESSOS JUDICIAIS-PENAIS DE PERNAMBUCO COLONIAL}

Quando se trata de compreender sobre a punibilidade de um estrato social, qualquer que seja a sociedade em comento, ao tentar entender a relação existente entre crime e castigo de determinando grupo social, uma das principais fontes a que se tem que recorrer, além da 
própria legislação existente à época, é aos processos jurídico-criminais existentes, com o fim de tentar compreender, para além do plano hipotético, como de fato aquela legislação penal posta era concretamente aplicada.

Por meio da realização de um mapeamento em arquivos públicos brasileiros, principalmente os existentes no Estado de Pernambuco, além de consultas a órgãos internacionais, sobretudo de Portugal e Holanda, foi possível obter registros documentais, acima de tudo documentação processual-criminal que possibilitaram a formação de um conhecimento mais aprofundado sobre a aplicação da legislação penal em Pernambuco.

O que acabou por se constatar foi que, além da aplicação das Ordenações do Reino na Capitania de Pernambuco, houve outros tipos de justiças existindo no mesmo espaço territorial, como, por exemplo, a justiça eclesiástica. Essa coexistência de vários tipos de direito na capitania pernambucana acabou por formar uma espécie de pluralismo jurídico bem similar, embora ainda em pequena proporção, ao existente na Europa medieval.

\subsection{Processos em Pernambuco}

Antes de qualquer coisa, é importante destacar a esparsa quantidade de processos criminais existentes atualmente nos órgãos públicos do período do Brasil Colônia. $\mathrm{Na}$ Assembleia Legislativa de Pernambuco - ALEPE inexiste qualquer arquivo/documento histórico anterior a 1835, ano da criação da respectiva assembleia. Da mesma forma, não existe qualquer processo criminal no Arquivo Público de Pernambuco atinente ao respectivo período colonial, bem como não há qualquer registro decisório no Supremo Tribunal Federal

- STF. Dos principais órgãos públicos, o único que possui algum registro de processos criminais na Capitania de Pernambuco durante o período colonial é o Memorial da Justiça de Pernambuco.

Em relação aos processos de cunho criminal existentes no Memorial da Justiça de Pernambuco que tenham relação com os delitos praticados durante o período colonial na Capitania de Pernambuco, verificou-se inexistir qualquer processo de Recife relacionado ao supracitado período.

Entretanto, embora inexista qualquer procedimento criminal referente ao Recife, no Memorial da Justiça de Pernambuco, existe o montante de 61 (sessenta e um) processos 
criminais da época de Pernambuco colonial, entre 1748 e 1813, oriundas de outras comarcas do Estado pernambucano.

Existem, portanto, no Memorial da Justiça de Pernambuco, o total de 29 (vinte e nove) processos criminais da comarca de Flores, entre os anos de 1778 e 1813; 1 (um) processo da comarca de Afogados da Ingazeira, de 1810, referente ao crime de homicídio; 14 (quatorze) processos da comarca de Serra Talhada entre 1803 e 1813, tendo como principais delitos objeto destes processos os crimes de homicídio, furto e estupro; 16 (dezesseis) procedimentos criminais da comarca de Garanhuns entre os anos de 1748 e 1813, os principais delitos analisados nesses processos da comarca de Garanhuns foram a investigação sobre a possível prática dos crimes de calúnia, injúria, sedução, homicídio, lesão corporal e furto (de escravos) e 1(um) processo criminal da comarca de Paudalho de 1807.

Nada obstante estes processos das mais diversas comarcas do Estado de Pernambuco possam ser localizados, não é possível realizar qualquer tipo de análise mais aprofundada desses documentos, sobretudo por causa do avançado grau de deterioração destes registros e da forma de escrita - português arcaico - utilizada na época. A leitura paleográfica de um pequeno processo, poderia levar mais de um ano, segundo relato do paleógrafo do Memorial da Justiça.

\subsection{Processos em Portugal}

A centralização do poder jurisdicional com a instituição do Governo-geral propiciou a criação de uma cultura jurídica mais uniforme e burocrática que acabou reproduzindo a estrutura jurídica da Coroa Portuguesa com uma justiça de primeira, segunda e terceira instância.

Este mesmo entendimento é corroborado com o pensamento de CRISTIANI (2011, p. 434) ao aduzir que "Com adoção do Governo-geral, os poderes locais foram diminuídos e houve, consequentemente, uma centralização das decisões, inclusive com maiores possibilidades de recursos para pleitear-se reforma das decisões".

Foi exatamente essa possibilidade de reforma das decisões no período do Governogeral que motivou a criação de uma segunda instância que só foi, então, criada em 1609, o Tribunal da Relação na Bahia que apreciava os recursos e agravos. Acima deste tribunal, só existia, então, a Casa da Suplicação (terceira instância), localizada na Metrópole portuguesa.

Entendendo, portanto, pela existência de um terceiro grau de jurisdição para as decisões realizadas pelos poderes jurisdicionais do Brasil colonial, que encaminhavam os 
processos em grau de recurso para a Casa da Suplicação em Portugal, é possível localizar no site do Arquivo Nacional da Torre do Tombo alguns acórdãos, embora pouco, de apelação de ação crime, em que eram partes habitantes da Capitania de Pernambuco, entre os anos de 1764 e 1776.

Dessas decisões disponíveis é possível detrair que a maioria dos réus eram sujeitos das classes sociais mais baixas, como, por exemplo, meretriz, aprendiz de ferreiro, dispenseiro de navio e clérigo inminoribus. As maiorias dos delitos julgados por esses acórdãos eram de crimes contra o patrimônio, pela prática de furto. Mas também, há decisões colegiadas pelos delitos de homicídio, contrabando e agressão física.

Em relação às decisões dessas sentenças, não é possível tirar um padrão em relação ao tratamento dispensado aos acusados, justamente pela existência de poucos acórdãos disponíveis, bem como pelo fato de a maioria dos acusados, senão todos, serem pertencentes à classe dos peões. Entretanto, dos acórdãos colhidos, extrai-se três tipos de decisões: (i) revogação da sentença; (ii) confirmação da sentença e condenação do réu a pagar as custas e; (iii) para que o caso seja julgado pelo juiz competente. Em relação a este ultimo tipo de decisão só foi proferida no julgamento do clérigo inminoribus pela prática do crime de homicídio, sendo julgado em 1774.

\subsection{Processos do Tribunal do Santo Ofício}

Devido à grande influência da Igreja Católica, existiu, também, a presença da justiça eclesiástica no Brasil colonial. Muito embora não tenha existido qualquer Tribunal do Santo Ofício no Brasil, houve a presença da Inquisição em terras brasileiras, através da Visitação do Santo Ofício. Assim, os acusados de cometer qualquer crime, segundo o seu Regimento Interno, eram julgados pelo Tribunal Inquisitorial de Lisboa.

O Tribunal do Santo Ofício possuía todo um Regimento Interno, considerando como delitos de grande lesividade aquelas condutas contra a fé, a moral e os costumes.

Desta forma, observando a atuação da Visitação do Santo Ofício no Brasil Colônia, através dos 13 (treze) processos existentes no site do Arquivo Nacional da Torre do Tombo datados entre 1595 e 1796, é possível verificar que, dos procedimentos do Tribunal do Santo Ofício que tinham moradores da Capitania de Pernambuco como réus, os delitos mais punidos eram o de bigamia e o de judaísmo. Acentue-se ainda que, muito embora essas condutas fossem graves para a Igreja Católica, não houve a cominação de penas vis e atrozes, como 
acontecia nas Ordenações Filipinas, sendo, nos processos analisados, as penas mais aplicadas a de abjuração em combinação com outras penalidades, em sua maioria degredos e/ou açoites.

Dos processos do Tribunal do Santo Ofício, existentes no site do Arquivo Nacional da Torre do Tombo, eram partes moradores da Capitania de Pernambuco das mais diversas classes sociais, tendo como réus desde senhores de engenho, juiz ordinário até oficial de barbeiro, ferreiro e ourives. Entretanto, dos processos do Tribunal do Santo Ofício existentes no supramencionado sítio eletrônico, verifica-se que a pena de açoite só foi aplicada aos homens da capitania pernambucana de baixa classe social.

A exemplo disto, tem-se que, em 1755, um marinheiro obteve como sentença pela prática do crime de bigamia a pena de ser abjurado de leve, açoitado publicamente, degredo por 05 (cinco) anos, penitências espirituais e pagamentos de custas. Pelo mesmo delito, muito embora já em 1780, um juiz ordinário, pelo cometimento do mesmo delito, teve como penalidade a abjuração de leve, degredo por 06 (seis) anos, penitências espirituais e pagamento de custas.

No ano de 1743, um oficial de barbeiro e um capitão foram condenados pelo delito de "Instituição de congregação ilegal para fins imorais", ambos obtiveram, como sanção, uma repreensão áspera, sendo, posteriormente, mandado em paz.

Já pela prática do crime de heresia, em 1595, o senhor de engenho, Luís do Rego Barros, obteve como condenação a obrigação de se confessar e comungar, além de penitências espirituais. De outra banda, o religioso, Antônio dos Anjos, em 1619, pelo mesmo delito, foi condenado a "não devolver o sermão ao suplicante nem o imprimir, por várias razões abonatórias, dar-lhe como carta como poderá exercitar seus cargos e ofícios".

Embora, como já exposto, da análise dos processos do Tribunal do Santo Ofício referentes aos moradores da Capitania de Pernambuco não se tenha constatado a aplicação da pena de morte, WOLKMER (1998) afirma que no Tribunal do Santo Ofício também era aplicada a pena de morte, praticada por meio da fogueira.

\subsection{Processos na Holanda}

Em relação aos documentos e processos existentes na Holanda da época do Brasil colonial durante o domínio holandês, o governo holandês mantém muitos documentos existentes no site do Arquivo Nacional Holandês, o sítio eletrônico Ga Het Na. Nele é possível encontrar documentos referentes à Nova Holanda, a maioria relacionados à Companhia das Índias Ocidentais - WIC. 
Embora seja possível encontrar esses documentos, não se pode afirmar que, entre os diversos documentos existentes no site do Arquivo Nacional Holandês, haja algum processo criminal, principalmente pela dificuldade na análise desses documentos em razão do tipo de caligrafia característico da época, bem como pelo fato desses documentos estarem todos escritos em holandês arcaico.

\section{CONSIDERAÇÕES FINAIS}

Ao analisar o processo de colonização na Capitania de Pernambuco, pode-se perceber que, de fato, a legislação portuguesa não foi imediatamente transplantada para as terras brasileiras, visto que, inicialmente, a Coroa lusitana abriu mão de sua jurisdição criminal, em favor dos donatários - fidalgos portugueses. Na Capitania de Pernambuco, quem adquiriu a jurisdição criminal foi o fidalgo Duarte Coelho Pereira, o seu donatário, ficando a cargo deste a aplicação das primeiras leis penais em solo pernambucano. O que, na verdade, mais aproximava o donatário à figura de um tirano, visto que a esta pessoa convergia o direito de criar as leis e o direito de aplicá-las.

Após a verificação da formação e aplicação do Direito Penal na Capitania de Pernambuco, observou-se que, com a falência do sistema de Capitanias Hereditárias e com a adoção do sistema de Governo-geral, houve o processo de centralização da jurisdição criminal pela metrópole portuguesa com a consequente retirada do ius puniendi das mãos dos donatários para as mãos dos Governadores-gerais. Na Capitania de Pernambuco, contudo, a retirada do poder de punir das mãos do donatário só ocorreu através do Alvará Régio de 05 de março de 1557. A partir de então, começa a existir a penetração das Ordenações do Reino em Pernambuco de forma paulatina. Contudo, dos códigos criminais, as Ordenações Filipinas, inegavelmente, foi o texto normativo português de maior aplicabilidade nestas bandas, tendo o seu Livro V, destinado ao direito penal.

Observou-se que as Ordenações Filipinas tinham como característica a cominação de penas muito cruéis e consideradas, não raramente, desproporcionais, sendo a pena de morte a mais cominada. Além disso, ficou estreme de dúvidas que as penas cominadas pelas Ordenações Filipinas, em alguns delitos, variavam de acordo com a classe social dos agentes envolvidos que, na Capitania de Pernambuco, se configurava por uma sociedade basicamente formada por nobres, peões, gentios e escravos. Uma Ordenação que muitas vezes confundia crime com religião, tipificando condutas que atentassem contra a religião oficial 
da Coroa Lusitana. Tinha como principal objetivo conter o grupo social por meio do temor, exaltando- se o caráter retributivo da pena.

Um detalhe importante que ficou evidenciado é que, durante o domínio dos holandeses na Capitania de Pernambuco, de 1630 a 1654, a Nova Holanda presenciou pela primeira vez um direito penal como ultima ratio, devido à revogação da figura típica de crimes menos gravosos. Entretanto, esse processo de revogação de algumas leis penais na Nova Holanda não tornou o direito penal mais benéfico com relação às suas penas, principalmente porque, embora com a existência da "política do perdão" do Conde Maurício de Nassau, a pena de morte continuou sendo aplicada, principalmente àqueles que se voltasse contra o domínio holandês. A pena de morte era a sanção por excelência, embora, não raramente, o Conde Maurício de Nassau perdoasse os criminosos, através da sua política do perdão.

Com a expulsão dos holandeses de Pernambuco, as Ordenações Filipinas voltaram a vigorar com suas penas atrozes, até a promulgação do Código Penal do Império de 1830, durando por mais de 02 (dois) séculos em terras pernambucanas, sem aproveitar em nada do diploma penal holandês.

Por fim, através dos mapeamentos e análises dos processos criminais existentes acerca do período colonial envolvendo moradores da Capitania de Pernambuco, realizados através de uma vasta pesquisa por meio de órgãos nacionais e, até, internacionais, verificouse que, em certo período da colonização, além de uma justiça "terrena", caracterizada pela composição de uma justiça bem hierarquizada com uma primeira, segunda e terceira instância, esta última com sede em Portugal, também houve a presença de uma justiça “divina”, com a coexistência de uma justiça eclesiástica que, muito embora tenha inexistido um Tribunal do Santo Ofício no Brasil, fez-se presente em Pernambuco por meio das Visitações do Santo Ofício.

Desta forma, além da constatação de uma forma diferenciada no tratamento dos criminosos, visto que não raramente sua posição social influía em sua punibilidade, seja essa diferenciação social realizada pela própria lei ou até mesmo pelo aplicador da lei, o julgador, é possível verificar a existência de uma forma de pluralismo, mesmo que em menor proporção, ainda que primitivo, do pluralismo jurídico medieval europeu, caracterizado pela coexistência de várias ordens normativas no mesmo espaço territorial. 


\section{REFERÊNCIAS}

ALVES, Roque de Brito. Direito Penal: parte geral. Recife: Intergraf editora, 2004.

ASSIS, Virginia Maria Almoêdo de. Ofícios do Rei: A circulação de homens e idéias na Capitania de Pernambuco. Disponível em <http://anpuh.org/anais/?p=14410>. Acesso em 10 de março de 2014.

BARBOSA, Artur Alves. A Capitania de Duarte Coelho e a Obra da Colonização Portuguesa no Brasil. Recife: Edição do Gabinête Português de Leitura, 1935.

BARLÉU, Gaspar. O Brasil Holandês sob o Conde João Maurício de Nassau. Trad.e notas Cláudio Brandão. Brasília: Senado Federal, Conselho Editorial, 2005. Vol. 43.

BRAGA, Pedro. Crime, Pena e Sociedade no Brasil Pré-republicano. Disponível em <http://www2.senado.gov.br/bdsf/item/id/879 $>$. Acesso em 13 de dezembro de 2013.

BRUNO, Aníbal. Direito penal: parte geral. Tomo I. Rio de Janeiro: Forense, 1978.

CAMARGO, Angélica Ricci. CAPITÃO E GOVERNADOR DE CAPITANIA. Disponível em: <http://linux.an.gov.br/mapa/?p=4861>. Acesso em 05 de Abril de 2016.

CEZARIO, Leandro Fazzollo. A Estrutura Judicial no Brasil Colonial: Criação, ordenação e implementação. $\langle$ http://www.boletimjuridico.com.br/doutrina/texto.asp?id=2045>. Acesso em 13 de dezembro de 2013.

CHAVES, Leandro Santos; SANCHEZ, Claudio José Palma. A Evolução Histórica do Direito Penal Positivado no Brasil. em <http://intertemas.unitoledo.br/revista/index.php/ETIC/article/viewFile/2238/2222>. Acesso em 15 de novembro de 2013.

CORRÊA, Ana Patrícia Thedin. Fantasia e Jurisdição: A recepção das normas jurídicas no Brasil pré-pombalino. Disponível em <http://jus2.uol.com.br/doutrina/texto.asp?id=10225 > Acesso em 17 de dezembro de 2013.

CRISTIANI, Cláudio Valentim. O direito penal no Brasil colonial. In: WOLKMER, Antônio Carlos (Org.). Fundamentos de história do direito. Belo Horizonte: Del Rey, 2011.

FILHO, Luís Francisco Carvalho. Impunidade no Brasil - Colônia e Império. Disponível em 〈http://www.scielo.br/scielo.php?pid=S0103-40142004000200011\&script=sci_arttext $>$. Acesso em 15 de novembro de 2013.

GOUlart, José Alípio. Da Palmatória ao Patíbulo (Castigos de Escravos no Brasil). Rio de Janeiro, Editora Conquista, 1971.

GUEDES, Roberto (org.). Dinâmica imperial no antigo regime português: escravidão, governos, fronteiras, poderes, legados (séc. XVII - XIX). Rio de Janeiro: Mauad X, 2011.

HESPANHA, António Manuel. Cultura jurídica europeia: Síntese de um milénio. Coimbra: Almedina, 2012.

HESPANHA, António Manuel. Cultura jurídica europeia: Síntese de um milénio. Lisboa: Europa-America, 2003. (Fórum da História). 
LARA, Silvia Hunold (Org.). Ordenações Filipinas: Livro V. São Paulo: Companhia das Letras, 1999.

MACIEL, José Fábio Rodrigues. A LEI DA BOA RAZÃO E A FORMAÇÃO DO DIREITO BRASILEIRO. Disponíve em:

$<$ http://www.cartaforense.com.br/conteudo/colunas/a-lei-da-boa-razao-e-a-formacao-dodireito-brasileiro/1668>. Acesso em 06 de abril de 2016.

MALHEIRO, Perdigão. A Escravidão no Brasil: Ensaio histórico-jurídico-social. 3 ed. Petrópolis, Vozes; Brasília, INL, 1976.

MARQUES, José Frederico. Tratado de Direito Penal. 1 ed atual. Campinas: Bookseller, 1997, p. 116.

MELO, José Antonio Gonsalves de e ALBUQUERQUE, Cleonir Xavier de. Cartas de Duarte Coelho a El Rei. 2 ed., Recife:FUNDAJ, Ed. Massangana, 1997.

MORAES, Mello. Corographia Histórica Chronographica, Genealogia, Nobiliaria, e Política do Império do Brasil. Rio de Janeiro: Typographia Americana de José Soares de Pinho, 1858.

NEQUETE , Lenine. O Poder Judiciário no Brasil: Crônica dos tempos coloniais. Brasília: Supremo Tribunal Federal, 2000. $2^{\circ}$ volume.

NETO, Vicente Amêndola Neto. História e evolução do Direito Penal no Brasil. Campinas: Julex Livros Ltda., 1997.

NEVES, Cylaine Maria das. A Vila de São Paulo de Piratininga: fundação e representação. São Paulo: Annablume;Fapesp,2007.

PARAISO, Maria Hilda Baqueiro. REVOLTAS INDÍGENAS, A CRIAÇÃO DO GOVERNO GERAL E O REGIMENTO DE 1548. Dis ponível em: <http://www.revista.ufpe.br/revistaclio/index.php/revista/article/viewFile/165/109>. Acesso em 05 de abril de 2016.

PINHO, Ruy Rebello. A Organização da Justiça, o Processo Penal e o Direito Penal no Brasil Holandês. Disponível em <http://www.revistas.usp.br/rfdusp/article/view/66217>. Acesso em 13 de junho de 2014.

PIERANGELI, José Henrique. Códigos Penais do Brasil: Evolução histórica. $2^{a}$ ed. São Paulo: Editora Revista dos Tribunais, 2004.

PORTUGAL. Regimento que levou Tomé de Souza governador do Brasil, Almerim, 17/12/1548. Disponível em:

$<$ http://lemad.fflch.usp.br/sites/lemad.fflch.usp.br/files/1.3._Regimento_que_levou_Tom de_Souza_0.pdf>. Acesso em 05 de abril de 2016 .

RAMOS, Arthur. Introdução à Antropologia Brasileira: As culturas europeias e europeizadas. $3^{\mathrm{a}}$ ed. Rio de Janeiro: Livraria-Editora da C.E.B., 1975. $4^{\circ}$ volume.

RIBEIRO, Flávia. Pena de Morte: A lei que mata. Disponível em <http://guiadoestudante.abril.com.br/aventuras-historia/pena-morte-lei-mata-434761.shtmll . Acesso em 07 de março de 2014.

SCHNEIDER, Giselda Siqueira da Silva. Apontamentos Históricos Acerca do Direito e da Justiça no Brasil Colonial. $\langle$ http://revistatempodeconquista.com.br/documents/RTC12/GISELDASCHNEIDER.pdf $>$.

Acesso em 12 de novembro de 2013. 
SILVA, Leonardo Dantas. Olinda, os tempos de duarte coelho. Disponível em: <http://www.luizberto.com/esquina-leonardo-dantas-silva/olinda-os-tempos-de-duartecoelho>. Acesso em 04 de abril de 2016.THOMPSON, Augusto F. G. Escorço Histórico do Direito Criminal Luso-brasileiro. São Paulo: Editora Revista dos Tribunais, 1976.

WEHLING, Arno; WEHLING, Maria José C.M.. Formação do Brasil Colonial. 2 ed. Rio de Janeiro: Nova Fronteira, 1999.

WOLKMER, Antônio Carlos. História do Direito no Brasil. Rio de Janeiro: Forense, 1998.

WOLKMER, Antônio Carlos (Org.). Direito e Justiça na América Indígena: Da conquista à colonização. Porto Alegre: Livraria do Advogado, 1998.

WOLKMER, Antônio Carlos (Org.). Fundamentos de História do Direito. $6^{\text {a }}$ ed. Belo Horizonte: Del Rey, 2011.

WOLKMER, Antônio Carlos (Org.). Humanismo e Cultura Jurídica no Brasil. Florianópolis: Fundação Boiteux, 2003. 